\title{
Increment patterns in otoliths and scales from mature Atlantic salmon Salmo salar
}

\author{
Brian K. Wells ${ }^{1,2, *}$, Kevin D. Friedland ${ }^{1}$, Lora M. Clarke ${ }^{1}$ \\ ${ }^{1}$ UMass/NOAA/CMER Program, Blaisdell House, University of Massachusetts, Amherst, Massachusetts 01002, USA \\ ${ }^{2}$ Present address: NOAA/NMFS Santa Cruz Laboratory, Santa Cruz, California 95060, USA
}

\begin{abstract}
This is the first work to note a similarity in increment patterns between otoliths and scales up to maturation, helping to understand better the biological and physical mechanisms guiding otolith and scale growth and increment formation. We demonstrate, with returning 1- and 2-sea winter Atlantic salmon Salmo salar, that transverse otolith thin sections to the core expose increments that represent seasonal growth during the marine phase. These increments are similar to those that form on scales, albeit with greater increment-width variability. From cage-reared fish, we noted that the number of increments on otoliths and scales formed during the period of marine residence is the same, and that the average mean deposition-time is slightly over $1 \mathrm{wk}$ in the first year and ca. $2 \mathrm{wk}$ in the second year.
\end{abstract}

KEY WORDS: Atlantic salmon $\cdot$ Otolith $\cdot$ Scale $\cdot$ Growth Resale or republication not permitted without written consent of the publisher

\section{INTRODUCTION}

Hard-part microstructure in fishes can serve to quantify ecological parameters (see review by Campana \& Thorrold 2001). Otolith increment patterns can represent daily periods. Other patterns with longer time steps, such as lunar cycles, may overlay daily patterns (e.g. Pannella 1971, Campana 1984, Linkowski 1996). Annual bands, representing seasonal shifts in growth rate, are commonly visible in many fish otoliths at microscopic, and often at whole otolith levels. Little work has been done on sub-seasonal increment patterns in otoliths and scales to the age of maturation. The value of recognizing these sub-seasonal increments would be that researchers could examine growth rates intra-annually. Such determinations are especially valuable in the case of sea-run salmon (Oncorhynchus spp., Salmo spp.) for which mortality, growth, and maturation are largely dependent on growth patterns within their first year at sea (Friedland 1998).
While scales have been useful for estimating these intra-annual growth patterns (Fisher \& Pearcy 1990, Friedland et al. 1993), they are vulnerable to loss, regeneration, and alterations during times of high calcium demand (Bilton \& Robins 1971). Otoliths, however, are inert structures that record growth and/or temporal histories, often regardless of a fish's resource demands or systemic condition (Campana \& Neilsen 1985, Maillet \& Checkley 1990).

The goal of this research is to compare otolith and scale increment-formation to the age of maturation, for a better understanding of the mechanisms involved. Much of this work has been conducted on salmon scales (Doyle et al. 1987, Barber \& Walker 1988, Fisher \& Pearcy 1990). Friedland et al. (1993) reported on tagging studies of Salmo salar post-smolts in the Gulf of St. Lawrence, during which fish were recaptured from the time of spring emigration into their first fall. Scale increments were deposited approximately weekly during the spring and summer when growth was fast, and 
approximately every $10 \mathrm{~d}$ during the fall when growth slowed. No work has examined otolith microstructure for Atlantic salmon beyond the daily increment patterns of very young, typically stream resident fish (Wright et al. 1991).

\section{MATERIALS AND METHODS}

Examination of otoliths and scales. To examine growth profiles, we randomly selected otoliths and scales from a sample of returning St. John salmon stock in 1998 that had spent 1 (1SW) or 2 (2SW) winters at sea. Fish were recovered in late summer and scales were removed. The fish were held for brood stock and, after they spawned in November, the otoliths were removed. Scales were cleaned and mounted between slides to be photographed at $12.5 \times$ magnification with a high-resolution digital camera $(3840 \times 3072$ pixels $)$ for image processing. We used Optimas 6.5 imaging software (Media Cybernetics) to measure increment widths on the scale along the axis of maximum diameter within the region representing marine growth, which was indicated by a dramatic increase in increment widths (Anonymous 1984, Friedland \& Haas 1996).

We embedded otoliths in Crystalbond 509 (Aremco Products) and made transverse cuts near the core. On the bottom surface (posterior), we ground to the core region with $600(\sim 30 \mu \mathrm{m})$ and 1200 $(\sim 15 \mu \mathrm{m})$ grit silicon carbide paper. The otolith section was flipped. On the exposed surface we used 30 and $3 \mu \mathrm{m}$ $\mathrm{Al}_{2} \mathrm{O}_{3}$ embedded lapping paper wetted with deionized water. We continued grinding to the core and stopped when the maximum number of increments was visible at 160 to $200 \times$ magnification. We polished the section with $0.3 \mu \mathrm{m} \mathrm{Al}_{2} \mathrm{O}_{3}$ powder suspended in deionized water on a low-nap cloth. When completed, the sections were 75 to $100 \mu \mathrm{m}$ thick. Otoliths were magnified 160 to $200 \times$, and focused to reveal the greatest number of increments at the surface. We photographed each otolith section with the digital camera. If necessary, we captured 2 images representing 2 light levels to reveal increments across the entire surface (Fig. 1b).

By examining the patterns of otolith increment width and overall shape, the period representing marine residence became apparent (Fig. 1a,b); however, we confirmed our judgments by examining a strontium/calcium (Sr/Ca) profile across the dorsal region of each otolith section. The otolith sections were coated with carbon and analyzed with a Cameca SX50 wavelength dispersive electron microprobe. We assayed a transect of $5 \mu \mathrm{m}$ points separated by $10 \mu \mathrm{m}$ (center to center) from near the core to the dorsal edge (40 nA, $20 \mathrm{kV}, 10$ s count time). Our methodology did not constitute a rigorous quantitative examination, but offered an efficient evaluation of trend.

We counted all increments in the dorsal region of the otolith, starting at the location where $\mathrm{Sr} / \mathrm{Ca}$ values began to increase and we stopped counting where Sr/Ca values dropped dramatically, which was representative of freshwater return (Fig. 1a,b). By counting back from the marine dorsal edge of the otolith the same number of increments as had been counted on the scale of the fish, we forced the number of increments to be compared between hard parts to be the same, and defined a starting increment for building a growth pro-
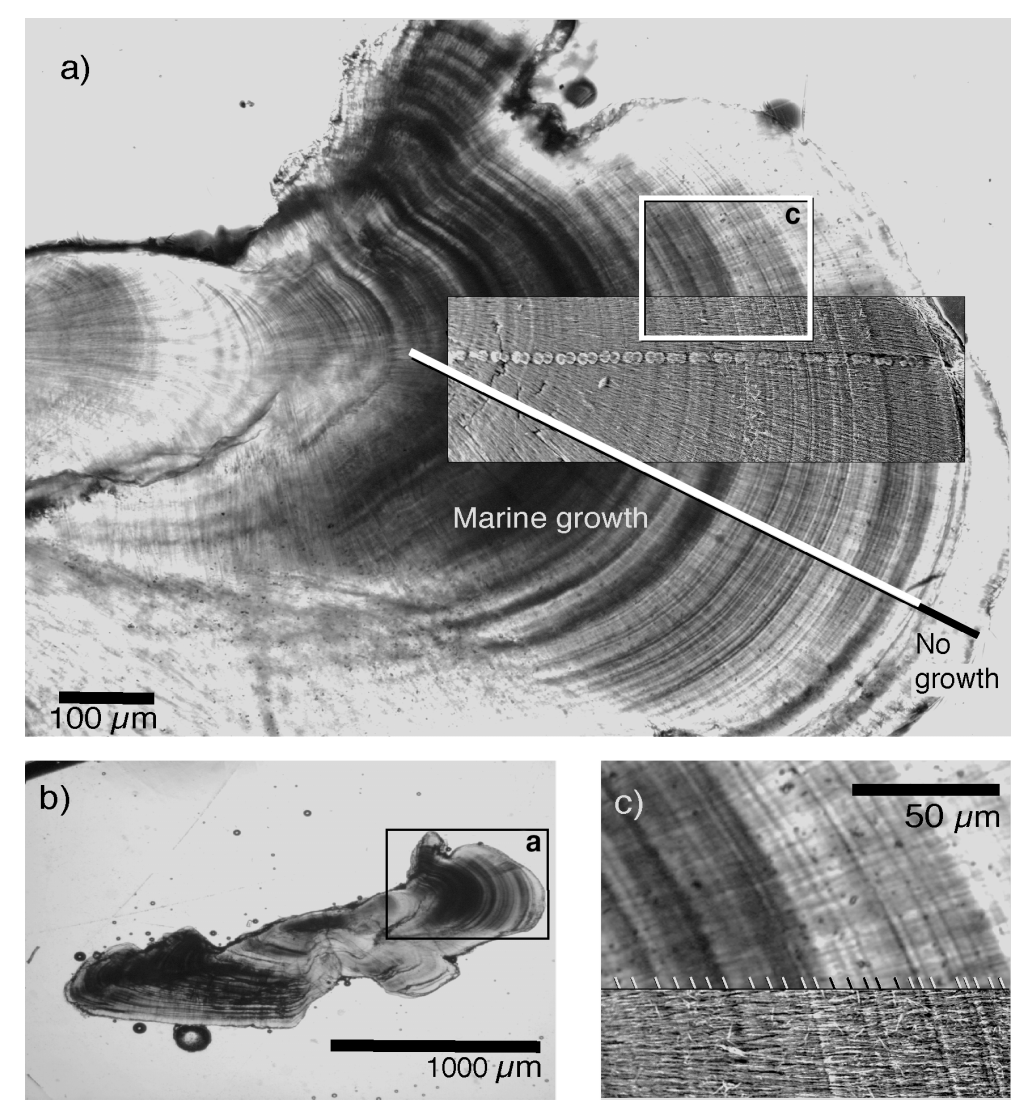

Fig. 1. Salmo salar. Otolith from a 2-sea winter (2SW) St. John return. (a) $125 \times$ image of otolith, showing the dorsal region and marine growth zone. Also included is a scanning electron micrograph (SEM) of the region, the electron microprobe transect, and the inset (c) is enlarged in (c) proper. (b) $20 \times$ image of the transverse section from which (a) and (c) were acquired. (c) Magnified region of inset shown in (a); our definition of increments is noted at the diagonal line 
file. From the defined starting point, we measured increment widths along a single transect which ran perpendicular to the increments and had a projected origin at the core. Increments were included if they could be tracked around the dorsal region. The sum of optical and digital magnification used for image processing was $\sim 500 \times$.

We compared growth profiles of otoliths and scales. Since the growth profiles are chronological, we considered them analogous to time series. First we examined the auto-correlation pattern for each otolith and scale increment width to evaluate seasonal periodicity patterns. We also examined cross-correlation coefficients between the 2 growth profiles to evaluate the equivalence of the low-frequency signals (see Chatfield 1996). The least-squares trend line was subtracted from each data series before calculation of auto- or cross-correlations.

Finally, we examined each otolith with scanning electron microscopy (SEM; Fig. 1a) to confirm the presence of increments seen with transmitted light. The carbon layer was removed with $0.3 \mu \mathrm{m} \mathrm{Al}_{2} \mathrm{O}_{3}$ slurry. To reveal surface structure, the otoliths were etched for $3.5 \mathrm{~min}$ with $0.25 \mathrm{M}$ EDTA. The otoliths were recoated with gold-palladium alloy and imaged with SEM (Fig. 1a).

Otolith and scale increment counts and deposition time. Otoliths and scales were collected from Atlantic salmon reared in sea cages for 465 and 832 d. Fish were vaccinated prior to being placed in sea cages and were raised on a fortified fish-meal diet. While at sea, only a moderate level of stress occurred in the spring and fall, when fish were anesthetized and sorted by size into various cages. Counts of scale circuli in the region representing marine growth were recorded along the maximum diameter of the scale, and 2 more count paths splayed 5 degrees to either side (Anonymous 1984). The 3 counts, which were very similar, were averaged. Otoliths were prepared similarly to those from wild salmon and Sr/Ca profiles across the dorsal surface from the core to the edge were assayed. Counts of increments were made along a transect starting at the point where Sr/Ca abruptly increased.

\section{RESULTS AND DISCUSSION}

\section{Otolith and scale growth patterns}

Increment counts in the marine zone on scales from 1SW St. John fish averaged $51(\mathrm{SE}=3.01, \mathrm{~N}=4)$ and for $2 \mathrm{SW}$ averaged $73(\mathrm{SE}=4.10 ; \mathrm{N}=3)$. Growth profiles from 1SW fish showed increasing growth into the first summer followed by declining growth rates into the first winter (Fig. 2a). As the next spring approached, growth increased again and finally, as the fish pre- pared to spawn, growth slowed. Although dampened, there was a similar seasonal pattern during the second year for 2SW fish (Fig. 2d).

Increment counts on otolith sections starting at the first increase in Sr/Ca and stopping at the second freshwater period (where Sr/Ca values dropped dramatically) were on average $56(\mathrm{SE}=5.01 ; \mathrm{N}=4)$ for $1 \mathrm{SW}$ fish and 77 ( $\mathrm{SE}=8.15 ; \mathrm{N}=3$ ) for $2 \mathrm{SW}$ fish. We defined a starting increment on the otolith from which to build a growth profile for comparison to the scale from the same fish. Back-counting increments from the edge of the marine dorsal zone to match scale counts for $1 \mathrm{SW}$ fish demonstrated that we should include increments at the first location on the otolith representative of the greatest Sr/Ca values. However, for 2SW fish, for which Sr/Ca increased less dramatically, otolith-derived growth profiles began before the Sr/Ca values typical of open-ocean water began. Once we defined a starting location on otoliths, we constructed growth profiles through the marine zone.

Auto-correlograms for detrended increment widths demonstrated that otolith and scale increment widths represented seasonal/cyclic growth (Fig. 2a,b,d,e). However, otolith growth patterns were more variable, as evidenced by the quicker dampening of the autocorrelations.

Despite the fact that otolith increment widths were more variable over time, the cross-correlations between otolith and scale growth patterns indicated that they both represent seasonal growth patterns. At a lag of zero, cross-correlations were low for both 1SW and 2SW fish $($ mean $=0.16 ; \mathrm{N}=7$ ), which likely represented some mismatch in our arrangement of time series. Such a mismatch could have resulted from branching in scale circuli, misidentification of first marine circuli on scales, otolith check marks (although seemingly rare), and unidentified increments in either scales or otoliths. Also, we cannot rule out that some mismatch may have resulted from undetected differences in the temporal pattern of otolith and scale increment deposition and/or width variation (Neilsen \& Geen 1985, Molony \& Choat 1990) occurring at a temporal resolution higher than that which we sampled. However, at an average lag of $-0.5(\mathrm{~N}=4$; range $=$ -6 to 5), the average maximum cross-correlation coefficient for $1 \mathrm{SW}$ fish was 0.34 (individual values $=0.47$ [Fig. 1c], 0.39, 0.32, and 0.17[insignificant]]. At an average lag of $-3(\mathrm{~N}=3$; range $=-1$ to -4$)$, the average maximum cross-correlation coefficient for 2SW fish was 0.27 (individual values $=0.34$ [Fig. 1f], 0.24, and $0.24)$. Note: the otolith profile from one 1SW fish was punctuated by narrow high-growth periods, and was not significantly correlated to scale growth. Also, correlations were lower for the $2 \mathrm{SW}$ group as a result of a more muted growth pattern following the first growth 


\section{1 sea winter}

a)

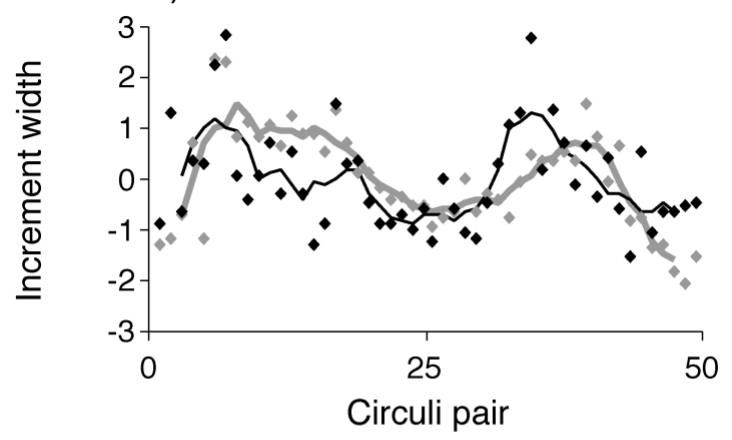

b)

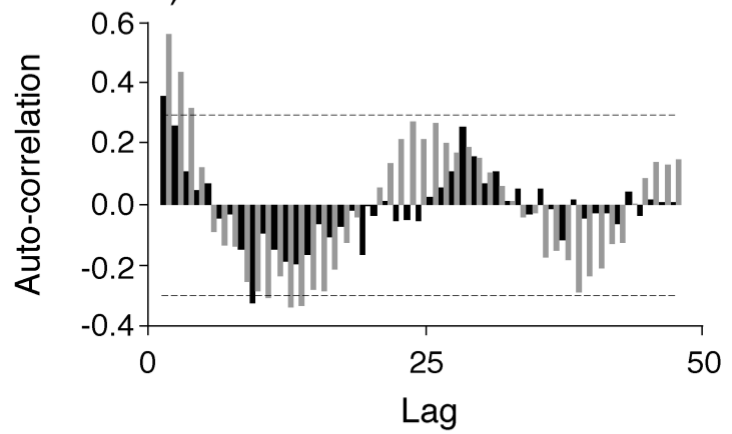

c)

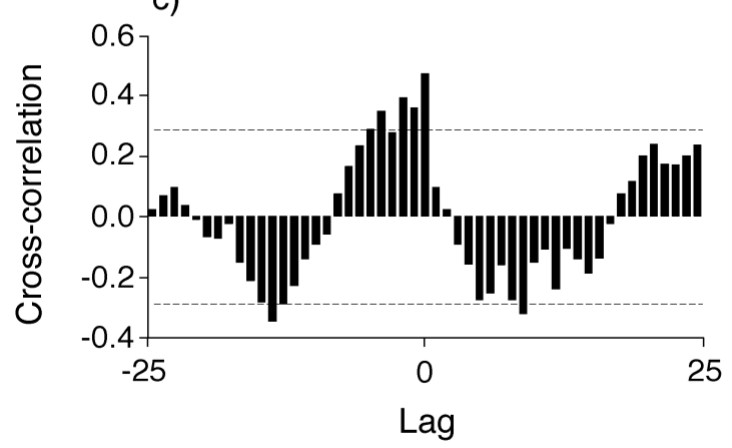

2 sea winter

d)

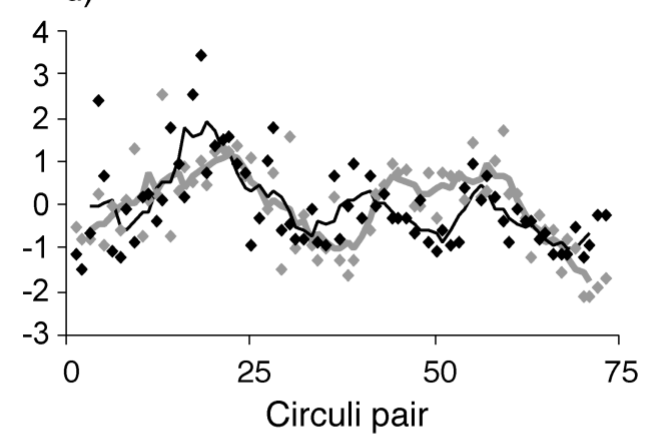

e)

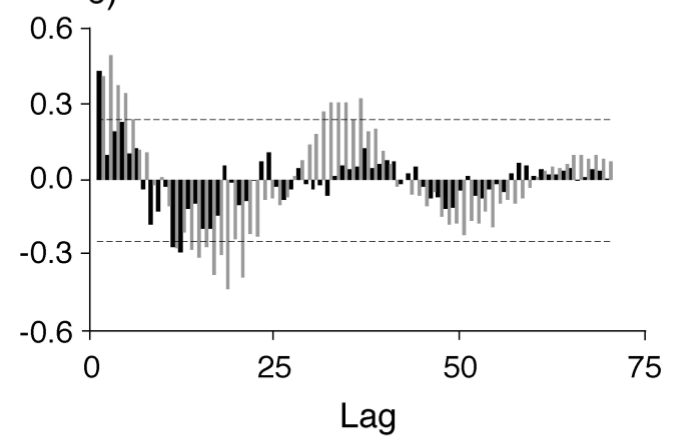

f)

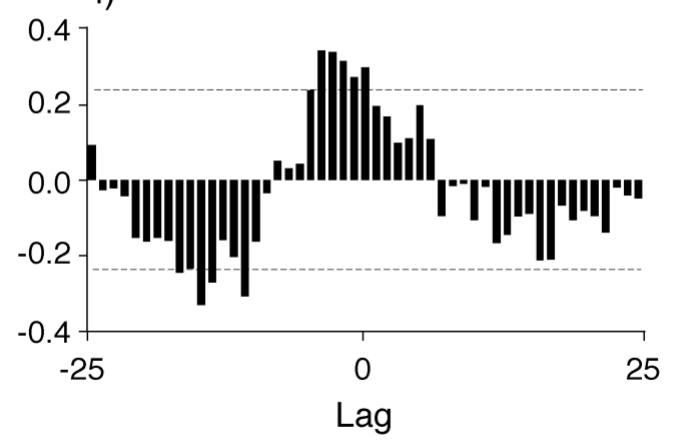

Fig. 2. Salmo salar. Growth profiles from the otoliths and scales of a 1- (1SW) and 2-sea winter (2SW) fish. (a) and (d) are standardized residuals of increment widths across the marine zone of the otolith $(\bullet)$ and of the scale ( ). Also shown is the growth profile smoothed with a moving average of 5 for the otolith (black line) and scale (gray line). (b) and (e) are autocorrelograms for the otolith (black bar) and scale profiles (gray bar). Bars that exceed dashed lines indicate correlations that are significantly $>0$ $\left( \pm 2 / \sqrt{ } N_{i}\right.$ Chatfield 1996). (c) and (f) are cross-correlograms between otolith and scale profiles. Bars that exceed dashed lines indicate correlations that are significantly greater than zero $( \pm 2 / \sqrt{ } \mathrm{N})$

season. Finally, we differenced the increment width data to examine the correlation of high-frequency variation between otolith and scale growth profiles (Chatfield 1996). Once the data had been differenced, there were no significant cross-correlation coefficients between otolith and scale profiles for any fish. This result indicated that the previously noted synchrony in growth patterns between otoliths and scales was driven by their similar response to an underlying lowfrequency (seasonal) trend (Thompson \& Page 1989).
Processes controlling scale and otolith accumulation are different, and do not always represent the fish's growth history with equal resolution. Scale growth is controlled predominately by biological processes (van Oosten 1957, Fouda 1979) and the scale grows proportionally compared to the body as a whole (Anonymous 1984, Campana \& Thorrold 2001). By contrast, otolith growth in salmon species is often decoupled from somatic growth (Wright 1991, Bradford \& Geen 1992), i.e. scale circuli patterns are more correlated to 
somatic growth than are otolith increment patterns (Fukuwaka 1998, Courtney et al. 2000). Unlike scales, otoliths have no physical connection to cellular tissue, are isolated in regulated endolymphatic fluid, and growth depends on physical conditions such as $\mathrm{pH}$, temperature, and ionic concentration (Payan et al. 1997, see review Campana \& Thorrold 2001, Takagi 2002). Also, much of the variation in otolith growth depends on the building rate of the protein matrix that offers nucleation sites for the inorganic matrix (see review Campana \& Thorrold 2001). The rate of calcification is a function of the amount of protein available, and it is the protein availability that is correlated to growth rate. Compounding this, for subyearling salmon the feeding intensity, temperature, and metabolism affect increment number and width (Volk et al. 1984, Neilsen \& Geen 1985, Wright 1991, Paperno et al. 1997, Wright et al. 2001). Lastly, as resting metabolism drives a carbonic-anhydrase mediated reaction, $\mathrm{Ca}\left(\mathrm{CO}_{3}\right)_{2}$ is produced in the endolypmh (Gauldie \& Nelson 1990, see review by Morales-Nin 2000), so that the otolith continues to accumulate even when somatic growth and feeding stop and available protein is limited. In our study, otolith regions representing the no-growth or nofeeding period were clear, without the obvious darker bands and structural heterogeneity associated with the protein matrix (Fig. 1a).

\section{Otolith and scale increment deposition}

Otoliths and scales were removed from 1 fish reared in marine waters for $465 \mathrm{~d}$ and from 6 fish reared for $832 \mathrm{~d}$. The number of increments within the marine zone of the scale from the fish reared for $465 \mathrm{~d}$ was 61 . The average increment count from scales collected from fish reared for $832 \mathrm{~d}$ was $73(\mathrm{SE}=3.56)$. Otolith increment counts were similar: the fish reared for $465 \mathrm{~d}$ had 58 increments, and the average in fish reared for $832 \mathrm{~d}$ was $76(\mathrm{SE}=4.57)$. Pearson's correlation coefficient between scale and otolith counts was 0.94 , and the values were not significantly different $(t$-test; $p$ > 0.05). The mean deposition times for increments on scales and otoliths were $8 \mathrm{~d}$ for the fish reared for $465 \mathrm{~d}$, and $11 \mathrm{~d}$ for fish reared for $832 \mathrm{~d}$. These results are consistent with scale circuli deposition timing for coho Oncorhynchus kisutch (Fisher \& Pearcy 1990) and pink Oncorhynchus gorbuscha salmon (Courtney et al. 2000) during their first growth season. At $2 \mathrm{yr}$, as metabolism and growth rate slow, the mean deposition time of increments becomes longer: 1SW fish had 2/3 the number of increments as 2SW fish. Assuming both age groups emigrated in mid-spring and returned in late summer, the mean deposition time of increments was slightly over $1 \mathrm{wk}$ for the first $1.25 \mathrm{yr}$ of life and $2 \mathrm{wk}$ for the following year.

\section{Conclusions}

Whereas previous work has demonstrated a similarity in counts of daily increments between otoliths and scales from sub-yearling fish (e.g. Kingsford \& Atkinson 1994), our findings relate to otolith increments deposited later in life. Friedland et al. (1993) documented that increment counts and width patterns on scales could be used to describe intra-annual growth of Atlantic salmon during their marine phase. Here, we have demonstrated that increment patterns in sectioned Atlantic salmon otoliths also reflect seasonal growth patterns during marine residence. If a more complete validation of the timing of increment deposition is undertaken, our findings, in combination with earlier findings that otolith increments are deposited on a daily basis for freshwater-resident juveniles (Wright et al. 1991), suggests that a researcher may be capable of constructing growth histories and ages throughout the entire life of the fish. Our findings are the first to quantify coincident patterns of variation in otolith and scale sub-seasonal increment counts and widths to the age of maturation for any fish species, and the results can be used to better understand the mechanisms controlling otolith and scale formation, and increment deposition.

Acknowledgements. Samples were obtained from US Fish and Wildlife Service, Fisheries and Oceans Canada, and Atlantic Salmon of Maine Inc. C. Reiss first suggested the time-series approach used here. We thank S. Bobko, M. Fuller, C. Royer, E. Volk and 4 anonymous reviewers for their thoughtful comments. Work was funded by a National Research Council Fellowship to B.K.W.

\section{LITERATURE CITED}

Anonymous (1984) Report of the Atlantic salmon scale reading workshop, Aberdeen, Scotland, 23-28 April 1984. ICES CM

Barber WE, Walker RJ (1988) Circuli spacing and annulus formation: is there more than meets the eye? The case for sockeye salmon, Oncorhynchus nerka. J Fish Biol 32: $237-245$

Bilton HT, Robins GL (1971) Effects of starvation, feeding, and light period on circulus formation on scales of young sockeye salmon (Oncorhynchus nerka). J Fish Res Board Can 28:1749-1755

Bradford MJ, Geen GH (1992) Growth estimate from otolith increment widths of juvenile chinook salmon (Oncorhynchus tshawytscha) reared in changing environments. J Fish Biol 41:825-832

Campana SE (1984) Lunar cycles of otolith growth in the juvenile starry flounder Platyichthys stellatus. Mar Biol 80: $239-246$ 
Campana SE, Neilsen JD (1985) Microstructure of fish otoliths. Can J Fish Aquat Sci 42:1014-1032

Campana SE, Thorrold SR (2001) Otoliths, increments, and elements: keys to a comprehensive understanding of fish populations? Can J Fish Aquat Sci 58:30-38

Chatfield C (1996) The analysis of time series: an introduction, 5th edn. Chapman \& Hall, New York

Courtney DL, Mortensen DG, Orsi JA (2000) Digitized scale and otolith microstructures as correlates of juvenile pink salmon size. North Pacific Anadr Fish Comm Bull 2: 337-345

Doyle RW, Talbot AJ, Nicholas RR (1987) Statistical interrelation of length, growth, and scale circulus spacing: appraisal of growth rate estimator for fish. Can J Fish Aquat Sci 44:1520-1528

Fisher JP, Pearcy WG (1990) Spacing of scale circuli versus growth rate in young coho salmon. Fish Bull 88:637-643

Fouda MM (1979) Studies on scale structure in the common goby, Pomatoschistus microps Kroyer. J Fish Biol 15: 173-183

Friedland KD (1998) Ocean climate influences on critical Atlantic salmon (Salmo salar) life history events. Can J Fish Aquat Sci 55(Suppl 1):119-130

Friedland KD, Haas RE (1996) Marine post-smolt growth and age at maturity of Atlantic salmon. J Fish Biol 48:1-15

Friedland KD, Reddin DG, Kocik JF (1993) Marine survival of North American and European Atlantic salmon: effects of growth and environment. ICES J Mar Sci 50: 481-492

Fukuwaka M (1998) Scale and otolith patterns prove growth history of Pacific salmon. North Pacific Anadr Fish Comm Bull 1:190-198

Gauldie RW, Nelson DGA (1990) Otolith growth in fishes. Comp Biochem Physiol A 97:461-474

Kingsford MJ, Atkinson MH (1994) Increments in otoliths and scales: How they relate to the age and early development of reared and wild larval and juvenile Pagrus auratus (Sparidae). Aust J Mar Freshw Res 45:1007-1021

Linkowski TB (1996) Lunar rhythms of vertical migrations coded in otolith microstructure of North Atlantic lanternfishes, genus Hygophum (Myctophidae). Mar Biol 124: 495-508

Maillet GL, Checkley DM Jr (1990) Effects of starvation on the frequency of formation and width of growth increments in sagittae of laboratory-reared Atlantic menhaden Brevoortia tyrannus larvae. Fish Bull 88:155-165

Editorial responsibility: Otto Kinne (Editor), Oldendorf/Luhe, Germany
Molony BW, Choat JH (1990) Otolith increment widths and somatic growth rate: the presence of a time lag. J Fish Biol 37:541-551

Morales-Nin B (2000) Review of the growth regulation processes of otolith daily increment formation. Fish Res 46: $53-67$

Neilsen JD, Geen GH (1985) Effects of feeding regimes and diel temperature cycles on otolith increment formation in juvenile Chinook salmon, Oncorhynchus tshawytscha. Fish Bull 83:91-101

Pannella G (1971) Fish otoliths: daily growth layers and periodical patterns. Science 173:1124-1127

Paperno R, Targett TE, Grecay PA (1997) Daily growth increments in otoliths of juvenile weakfish, Cynoscion regalis. Experimental assessment of changes in increment width with changes in feeding rate, growth rate, and condition factor. Fish Bull 95:521-529

Payan P, Kossman H, Watrin A, Mayer-Gostan N, Boeuf G (1997) Ionic composition of endolymph in teleosts: origin and importance of endolymph alkalinity. J Exp Biol 200: $1905-1912$

Takagi Y (2002) Otolith formation and endolymphatic chemistry: a strong correlation between the aragonite saturation state and $\mathrm{pH}$ in the endolymph of the trout otolith organ. Mar Ecol Prog Ser 231:237-245

Thompson KR, Page FH (1989) Detecting synchrony of recruitment using short, autocorrelated time series. Can J Fish Aquat Sci 46:1831-1838

van Oosten J (1957) The skin and scales. In: Brown ME (ed) The physiology of fishes. Academic Press, New York, p 207-244

Volk EC, Wissmar RC, Simenstad CA, Eggers DM (1984) Relationship between otolith microstructure and the growth of juvenile chum salmon (Oncorhynchus keta) under different prey rations. Can J Fish Aquat Sci 41:126-133

Wright PJ (1991) The influence of metabolic rate on otolith increment width in Atlantic salmon, Salmo salar L. J Fish Biol 38:929-934

Wright PJ, Rowe D, Thorpe JE (1991) Daily growth increments in the otoliths of Atlantic salmon parr, Salmo salar L., and the influence of environmental factors on their periodicity. J Fish Biol 39:103-114

Wright PJ, Fallon-Cousins P, Armstrong JD (2001) The relationship between otolith accretion and resting metabolic rate in juvenile Atlantic salmon during a change in temperature. J Fish Biol 59:657-666

Submitted: February 19, 2003; Accepted: September 30, 2003 Proofs received from author(s): October 31, 2003 